\title{
Nutritional evaluation of the protein of dried tomato pomace in the rat
}

\author{
By N. J. DROULISCOS \\ Department of Biology, Nuclear Research Centre 'Democritos', Aghia Paraskevi, \\ Attiki, Greece
}

(Received 6 Fanuary 1976-Accepted 7 Fैune 1976)

\begin{abstract}
I. Nutritional evaluation of dried tomato pomace (D'TP-20) as a source of protein was carried out using weanling rats. Comparisons were made with casein (CS), soya-bean meal (SOM-45) and the hydrocarbon-grown yeast Toprina (BP-T). The growth-promoting effects of the diets were evaluated over a period of $28 \mathrm{~d}$ of ad lib. feeding.

2. The unsupplemented DPT-20 had a protein efficiency ratio (PER) of $2 \cdot 18 \pm 0 \cdot{ }^{3}$ and a net protein utilization (NPU) of 0.55 . The addition of DL-methionine $(5 \mathrm{~g} / \mathrm{kg}$ ) resulted in a PER of $1.74 \pm 0.15(t 2.99, P<0.01)$ and a NPU of 0.40 , while the addition of an amino acid mixture resulted in a PER of $2.33 \pm 0.08(t \mathrm{I} .84, P<0.1)$ and a NPU of 0.70 .

3. The reason for the decrease in growth and the reduced PER and NPU values recorded for the methionine-supplemented group of rats is not clear and it is discussed in connexion with an imbalance or a slight toxicity caused by the added amino acid.
\end{abstract}

Exploitation of agricultural by-products may make a substantial contribution towards better and more economic feeding of livestock. The nutritive potential of a number of available by-products is, however, inadequately known, a fact that discourages their efficient utilization in animal feeding. In view of the shortage and the high prices of protein feeding-stuffs, some of these by-products could provide part of the protein needed by animals. In this respect it is clear that the country's resources in such products need to be fully developed and thoroughly evaluated nutritionally.

Stählin (1957) and Maymone \& Tiberio (1959) have provided information on the nutritive value of the tomato-seed oilcake meal, a by-product obtained after the extraction of the oil from the tomato seed. The oilcake has a crude protein (CP) (nitrogen $x$ 6.25 ) content ranging from 340 to $400 \mathrm{~g} / \mathrm{kg}$ and its value as a protein supplement for broilers is considered to be good (Kalaisakis, Papadopoulos, Boufidis, Zacharioudakis $\&$ Gourakou, 1970 ). Dried tomato pomace is composed of tomato seeds and skin that remain after the expulsion of the juice. In the dry state, as fed, it provides approximately $95^{\circ} \mathrm{g}$ dry matter and $195^{-21} 5 \mathrm{~g} \mathrm{CP} / \mathrm{kg}$. The annual production of dried pomace in Greece is in the order of $3000 \mathrm{t}$, with good prospects for future increase.

The purpose of this study was to assess, by a series of rat bioassay procedures, the protein quality of dried pomace, and obtain information regarding its nutritional value. The biological indices measured were the protein efficiency ratio (PER), the net protein utilization (NPU) and the growth response of the experimental animals to amino acid supplementation. The amino acid profile was compared to other protein supplements and the interpretation of the results obtained is discussed. 
EXPERIMENTAL

\section{Sampling of dried tomato pomace}

A representative sample of $100 \mathrm{~kg}$ dried tomato pomace (DTP-20) was obtained from a tomato-juice processing plant in northern Greece and kept in a cool, dry place in the laboratory for further use. Portions of this material were taken for the chemical tests and the animal experiments.

\section{Analytical procedures}

Standard methods for moisture, $\mathrm{CP}$ ( $\mathrm{N}$ content determined by Kjeldahl procedure) diethyl ether extract, crude fibre and ash were followed as outlined by the Association of Official Analytical Chemists (1970). Total sugars were estimated by the method of Dubois (1956). Total energy was determined in a bomb calorimeter (Parr Instruments, Illinois, USA).

Amino acids were determined by column chromatography using a Spinco-Beckman I 20-C automatic analyser (Beckman Instruments, Palo Alto, California, USA). The diethyl ether-extracted sample was weighed and mixed with $6 \mathrm{M}-\mathrm{HCl}$ in a glass tube, frozen in liquid $\mathrm{N}_{2}$ and vacuum sealed. The hydrolysis was done for $24 \mathrm{~h}$ at $110^{\circ}$.

The hydrolysate was filtered, the acid removed under reduced pressure at $42^{\circ}$, washed several times with distilled water and re-dried. The dry sample was taken up in ro $\mathrm{ml}$ distilled water and passed through a Dowex-50 cation-exchange column. It was washed with $200 \mathrm{ml}$ distilled water and amino acids were eluted with $150 \mathrm{ml}$ I M- $\mathrm{NH}_{4} \mathrm{OH}$ (Christias, Couvaraki, Georgopoulos, Macris \& Vomvoyanni, 1975). The eluate was evaporated to dryness. Amino acids were taken up in $4 \mathrm{ml} \mathrm{O} \cdot \mathrm{I}$ M-sodium citrate buffer, $\mathrm{pH}$ 2.2. Sulphur-containing amino acids were pretreated with performic acid (Lewis, 1966). The composition of DTP-20 is given in Table r.

\section{Animals and management}

The rats used in these trials were of both sexes and of the Wistar strain, $25-28 \mathrm{~d}$ old, weighing initially $43-45 \mathrm{~g}$ for the PER tests and $5 \circ \mathrm{g}$ for the NPU tests. In all tests they were individually caged in specially designed cages constructed in the workshop of the technical department of the Research Centre, and made of Plexiglass, with feeding troughs that allowed accurate measurement of the daily food offered. Food and water were given ad lib. The animals were kept under controlled temperature and humidity conditions in the animal house (temperature $2 \mathrm{I} \pm \mathrm{I}^{\circ}$, relative humidity $55 \%$ ).

\section{Experimental}

The composition of four of the experimental diets is given in Table 2; protein sources tested were: DTP-20, casein (CS), soya-bean meal (SOM-45) and Toprina hydrocarbon-grown yeast (BP-T). A quantity of $4 \mathrm{~kg}$ of each was prepared and used for the tests; samples were taken for chemical analysis and the analytical values were used for all subsequent calculations. 
Table I. Composition ( $\mathrm{g} / \mathrm{kg}$ ) of dried tomato pomace* $D T P-20$

\begin{tabular}{|c|c|c|c|}
\hline \multicolumn{4}{|c|}{ Proximate composition } \\
\hline Moisture & $66 \cdot 0$ & $\mathrm{~N}$-free extract & 433.5 \\
\hline Total nitrogen & $3 I \cdot 2$ & Total sugars & $51 \cdot 0$ \\
\hline Crude protein $(\mathrm{N} \times 6.25)$ & 195.0 & Total ash & 34.0 \\
\hline Diethyl ether extract & $159 \cdot 0$ & Total energy (MJ/kg) & I9' I \\
\hline Crude fibre & II $2 \cdot 5$ & & \\
\hline \multicolumn{4}{|c|}{ AMINO ACID CONTENT } \\
\hline Phenylalanine & $7 \cdot 6$ & Aspartic acid & I8. I \\
\hline Tyrosine & $7 \cdot 6$ & Glutamic acid & $3 I \cdot 9$ \\
\hline Histidine & 4.9 & Serine & $8 \cdot 2$ \\
\hline Isoleucine & $6 \cdot 6$ & Glycine & $9 \cdot 2$ \\
\hline Leucine & $9 \cdot 9$ & Alanine & $7 \cdot 6$ \\
\hline Methionine & $3 \cdot 5$ & Proline & $8 \cdot 4$ \\
\hline Cystine & $3 \cdot r$ & Total amino acids & I66.9 \\
\hline Valine & $8 \cdot 8$ & & \\
\hline Arginine & $14 \cdot 2$ & & \\
\hline Lysine & $8 \cdot 9$ & & \\
\hline Threonine & $6 \cdot 2$ & & \\
\hline Total essential amino acids & $83 \cdot 5$ & & \\
\hline
\end{tabular}

Table 2. Composition $(\mathrm{g} / \mathrm{kg})$ of the experimental diets containing dried tomato pomace* $(D T P-20)$, casein $(C S)$ or Toprina hydrocarbon-grown yeast $\dagger(B P-T)$ as the protein source, and a protein-free diet

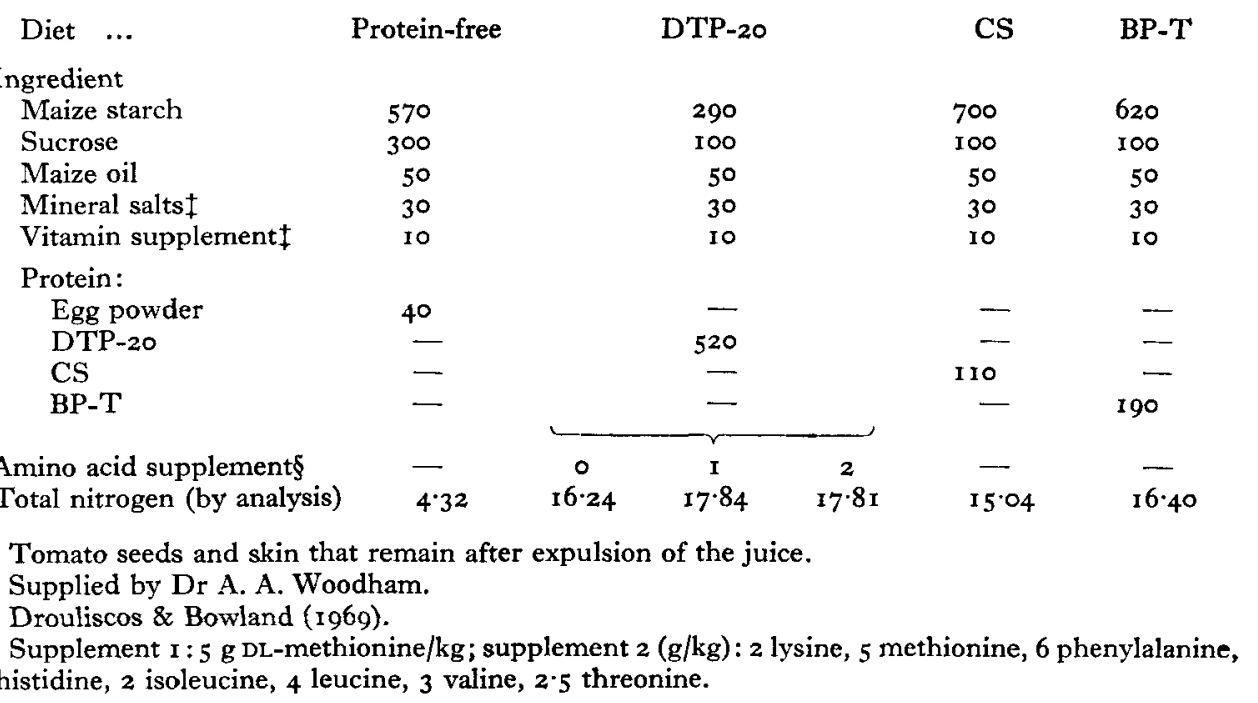

\section{Nutritional indices for rats}

The PER was determined using two groups of five male rats, and values calculated from results for body-weight gain (BG) and the CP intake (CPI) over a $28 \mathrm{~d}$ period with a diet providing $16 \mathrm{~g} \mathrm{~N} / \mathrm{kg}$. The PER was calculated as BG:CP1. The NPU was determined for each test diet using a total of eight rats (duplicate determinations using two males and two females for each determination) and for the protein-free diet, 


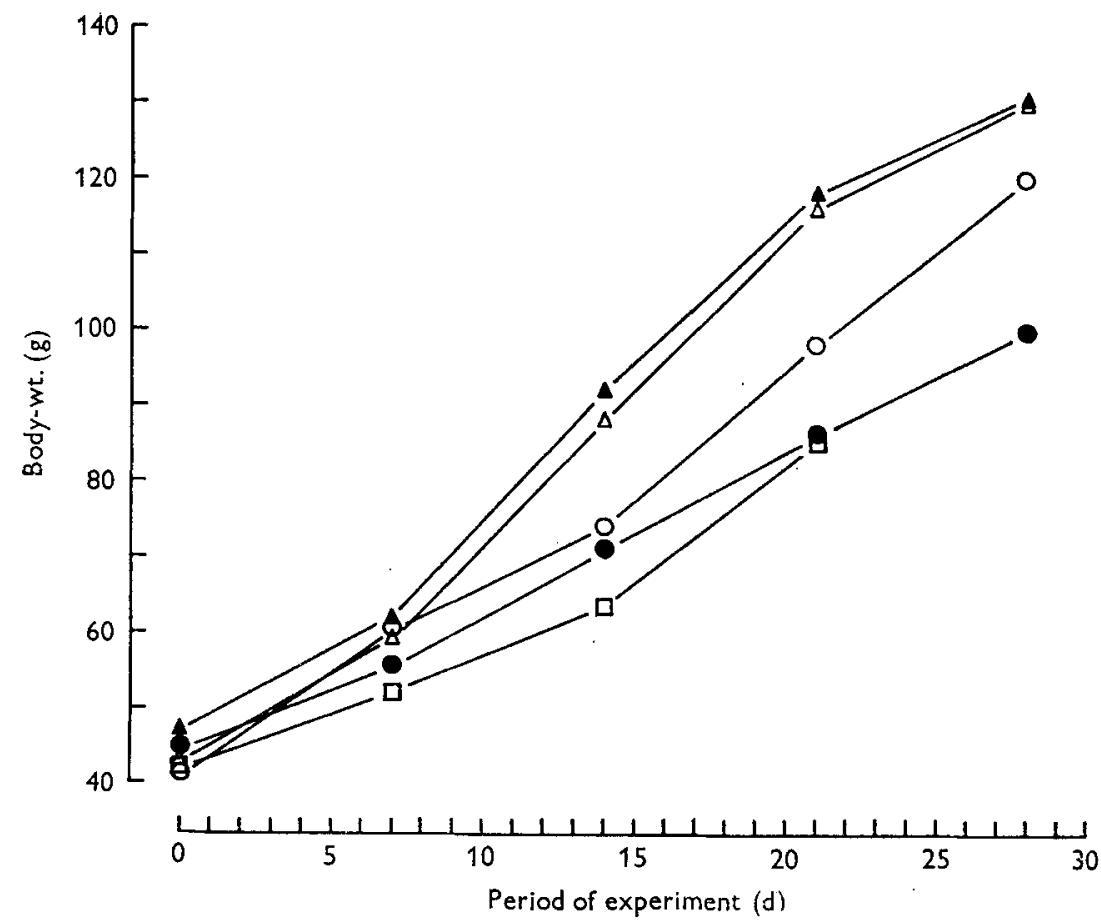

Fig. I. Pattern of growth for the experimental rats, fed on diets with dried tomato pomace (tomato seeds and skin that remain after expulsion of the juice) (DTP-2o), casein (CS) or Toprina hydrocarbon-grown yeast $(\mathrm{BP}-\mathrm{T})$ as the sole protein source. $(\mathrm{O}-\mathrm{O})$, DTP-20; $(0)$, DTP-20 supplemented with DL-methionine $(5 \mathrm{~g} / \mathrm{kg}) ;(\Delta-\Delta)$, DTP-20 supplemented with a mixture of amino acids; $(\boldsymbol{\Delta}-\mathbf{\Lambda}), \mathrm{CS} ;(\square-\square), \mathrm{BP}-\mathrm{T}$. For details of the diets and of amino acid mixture, see Tables $I$ and 2 .

duplicate determinations using a similar group of two male and two female rats. NPU was derived from the formula: $\frac{B_{K}-\left(B_{F}-I_{F}\right)}{I_{K}}$, where $B_{K}$ and $B_{F}$ are the carcass $\mathrm{N}$ contents for the test group and the protein-free group respectively, and $I_{K}$ and $I_{F}$ are the intakes of the test group and the protein-free group respectively. Determination of the NPU value was carried out by the procedures of Bender \& Miller (1953) and Miller \& Bender (1955).

\section{RESULTS AND DISCUSSION}

Values for the composition of DTP-2o given in Table $\mathrm{I}$ indicate that its CP content ( $195 \mathrm{~g} / \mathrm{kg})$ is not high compared to that of SOM-45 $(457 \mathrm{~g} / \mathrm{kg}), \operatorname{CS}(854 \mathrm{~g} / \mathrm{kg})$ or BP-T $(539 \mathrm{~g} / \mathrm{kg})$.

In feeding trials with rats fed at a level of $520 \mathrm{~g} \mathrm{DTP-20} / \mathrm{kg}$ diet (Table 2), the results obtained in terms of the growth response indices PER and NPU were higher than those anticipated for a product of this type. DTP-20 as fed and under the conditions of these experiments was readily acceptable by the rats, the food intake did not fluctuate throughout the experimental period and no spilling of food occurred.

The growth pattern of rats fed on the DTP-20 and the CS diets is shown in Fig. I. A 
Table 3. Essential amino acid $(A A)$ requirement (mg $A A / g$ crude protein (nitrogen $\times 6.25$ ) intake per d) for growth in the rat and approximate amounts of each $A A$ provided by dried tomato pomace* $(D T P-20)$ casein $(C S)$, soya-bean meal $(S O M-45)$ and Toprina hydrocarbon-grown yeast $\uparrow(B P-T)$

\begin{tabular}{|c|c|c|c|c|c|c|}
\hline & \multicolumn{2}{|c|}{ Requirement } & & & & \\
\hline & (US) National & & \multicolumn{4}{|c|}{ Protein source } \\
\hline & Council (1962) & (I 966) & DTP-20 & $\operatorname{cs} t$ & SOM-45 & BP-T§ \\
\hline Phenylalanine & \multirow{2}{*}{$90 \|$} & \multirow{2}{*}{$69 \|$} & 39 & 52 & 52 & 30 \\
\hline Tyrosine & & & 39 & 34 & 30 & 28 \\
\hline Histidine & 30 & 35 & 25 & 34 & 35 & 14 \\
\hline Isoleucine & 50 & 53 & 34 & 62 & 45 & 30 \\
\hline Leucine & 80 & 64 & $5 I$ & I 10 & 75 & 58 \\
\hline Lysine & 90 & 53 & 46 & 82 & 60 & 66 \\
\hline Methionine & \multirow{2}{*}{$60 \|$} & \multirow{2}{*}{$42 \|$} & I8 & 32 & 16 & 12 \\
\hline Cystine $\}$ & & & 16 & 5 & 16 & 10 \\
\hline Threonine & 50 & 43 & 32 & 43 & 37 & 45 \\
\hline Valine & 70 & 53 & 45 & 66 & 50 & 35 \\
\hline Arginine & - & 18 & 73 & 36 & 70 & 40 \\
\hline Tryptophan & I5 & 10 & nd & 20 & Io & 9 \\
\hline
\end{tabular}

nd, Not determined.

* Tomato seeds and skin that remain after expulsion of the juice.

$\uparrow$ Supplied by Dr A. A. Woodham.

$\ddagger$ Eggum (1973).

$\S$ Woodham \& Deans (1973).

II Combined value for the two AA.

supplement of methionine appeared to reduce the growth of the rats receiving the DTP-20 diet, while a supplement of mixed amino acids improved it.

The amino acid profile of DTP-20 (Table 3 ) suggests that methionine and cystine are limiting. The remaining amino acids were present at levels that are near to or lower than those recommended by the (US) National Research Council (I962), and referred to by Smith (1966), as meeting the requirements of the growing rat (Table 3 ).

When the values of essential amino acids were expressed in $\mathrm{mg} / \mathrm{g}$ total essential amino acids (Table 4 ) DTP-20 was comparable with CS, SOM-45 and BP-T, but when expressed as the ratio, essential amino acid content: $N$ content, the value for DTP-20 (2.07) was slightly higher than that of BP-T (2.02) but lower than those of SOM-45 $(2 \cdot 45)$ and CS $(3 \cdot 23)$. Similar conclusions may be drawn from the essential amino acid indices, the values being $68 \cdot \mathrm{I}, 59 \cdot 5,78 \cdot 5$ and $87 \cdot \mathrm{I}$ for DTP-20, BP-T, SOM-45 and CS respectively.

The PER of unsupplemented DTP-20 was $2 \cdot 18$ and the NPU 0.55 . Values previously reported for SOM-45 by Drouliscos \& Bowland (I969) were PER 2.40, NPU 0.80, and the present results gave a PER of 2.20 and 2.94 for the BP-T and CS respectively (Table 5).

Supplementation with $5 \mathrm{~g}$ DL-methionine $/ \mathrm{kg}$ resulted in a decrease of $20.2 \%$ in the PER (from $2 \cdot 18$ to 1.74$)(t 2.99, P<0.01$ ), and a decrease of $27.3 \%$ in the NPU (from 0.55 to 0.40 ).

This unexpected and anomalous response to methionine supplementation remains 
Table 4. Comparison of the essential amino acid $(A A)$ patterns (mg/g total essential $A A)$ of dried tomato pomace* (DTP-20), casein (CS), soya-bean meal (SOM-45) and Toprina hydrocarbon-grown yeast $\uparrow(B P-T)$

\begin{tabular}{|c|c|c|c|c|c|}
\hline & & & Protein & & \\
\hline $\mathrm{AA}$ & $D^{\prime} T P-20$ & $\mathrm{CS}$ & SOM-45 & $\mathrm{BP}-\mathrm{T}$ & $\begin{array}{c}\text { Reference } \\
\text { whole-egg } \\
\text { protein }+\end{array}$ \\
\hline Phenylalanine & II 8 & 102 & I33 & 93 & II 4 \\
\hline Isoleucine & 103 & I $2 I$ & II 6 & 93 & I 29 \\
\hline Leucine & I 54 & 232 & I9I & I79 & 172 \\
\hline Lysine & 139 & 159 & 53 & 204 & 125 \\
\hline Methionine + cystine & $103(55+48)$ & 72 & $8 \mathrm{I}$ & 68 & 108 \\
\hline Tryptophan & $3 \mathbf{I} \|$ & 39 & 26 & 29 & $3 \mathbf{I}$ \\
\hline Valine & 136 & 127 & 128 & 108 & $14 I$ \\
\hline $\begin{array}{l}\text { Threonine } \\
\text { Tyrosine }\end{array}$ & $\begin{array}{r}97 \\
118\end{array}$ & $\begin{array}{l}83 \\
66\end{array}$ & $\begin{array}{l}95 \\
77\end{array}$ & $\begin{array}{r}139 \\
86\end{array}$ & $\begin{array}{l}99 \\
8 \mathrm{I}\end{array}$ \\
\hline $\begin{array}{l}\text { Total essential AA } \\
\text { (mg/g nitrogen) }\end{array}$ & 2066 & 3229 & 2448 & 2024 & $32 \times 5$ \\
\hline $\begin{array}{l}\text { Ratio, essential } \\
\text { AA content: } N \text { content }\end{array}$ & $2 \cdot 07$ & $3 \cdot 23$ & $2 \cdot 45$ & $2 \cdot 02$ & $3 \cdot 22$ \\
\hline Essential AA Index§ & $68 \cdot 1$ & $87 \cdot 1$ & $78 \cdot 5$ & $59 \cdot 5$ & - \\
\hline $\begin{array}{l}\text { * Tomat } \\
\dagger \text { Suppli } \\
\ddagger \text { FAO/V } \\
\S \text { Calcula } \\
\| \text { Value }\end{array}$ & $\begin{array}{l}\text { seeds and skin } \\
\text { d by Dr A. A. } \\
\text { HO (1965). } \\
\text { ed as described } \\
\text { om Scott, Nesh }\end{array}$ & $\begin{array}{l}\text { at remain } \\
\text { odham. } \\
\text { Oser ( } \\
\text { n \& You }\end{array}$ & expulsi & the juic & \\
\hline
\end{tabular}

totally unclear. A similar decrease of $16.7 \%$ in the NPU value (from 0.36 to 0.30 ) for pigs fed on a barley-grown biomass of Aspergillus oryzae supplemented with $2 \mathrm{~g}$ L-methionine/kg has recently been reported by Smith, Palmer \& Reade (1975).

The added amino acid supplement (Table 2) increased the lysine, methionine, phenylalanine, histidine, isoleucine, leucine, valine and threonine contents to amounts similar to those recommended by the (US) National Research Council (1962) as meeting the requirements of the growing rat. Amino acid supplementation resulted in an increase of $6.9 \%$ in the PER (from 2.18 to 2.33$)(t \mathrm{I} \cdot 84, P<0.1)$ and of $27.3 \%$ in the NPU (from 0.55 to 0.70 ). These responses are in agreement with the growth pattern obtained for the rats receiving the amino acid supplement (Fig. r).

In the present study supplementation with DL-methionine at the rate of $5 \mathrm{~g} / \mathrm{kg}$ diet increased the total methionine to approximately $70 \mathrm{mg} / \mathrm{g} \mathrm{CP}$ per $\mathrm{d}$. This value exceeded by approximately ro $\mathrm{mg}$ the methionine requirement recommended by the (US) National Research Council (1962), and by $30 \mathrm{mg}$ the requirement referred to by Smith (1966) (Table 3).

At present only a hypothesis can be made regarding this unexpected response to methionine supplementation. The possibility of a nutritional imbalance, or of a slight toxicity created by the excess supply of methionine, is not unlikely but strong and supportive evidence is lacking. Muramatsu, Odagiri, Morishita \& Takeuchi (I97I) have reported that the addition of $50 \mathrm{~g}$ methionine $/ \mathrm{kg}$ diet caused a $125 \%$ reduction in growth in rats (estimated as: roo- body-weight of amino acid-supplemented group : body-weight of control group $\times$ I00); methionine at these high levels of intake 
Vol. 36

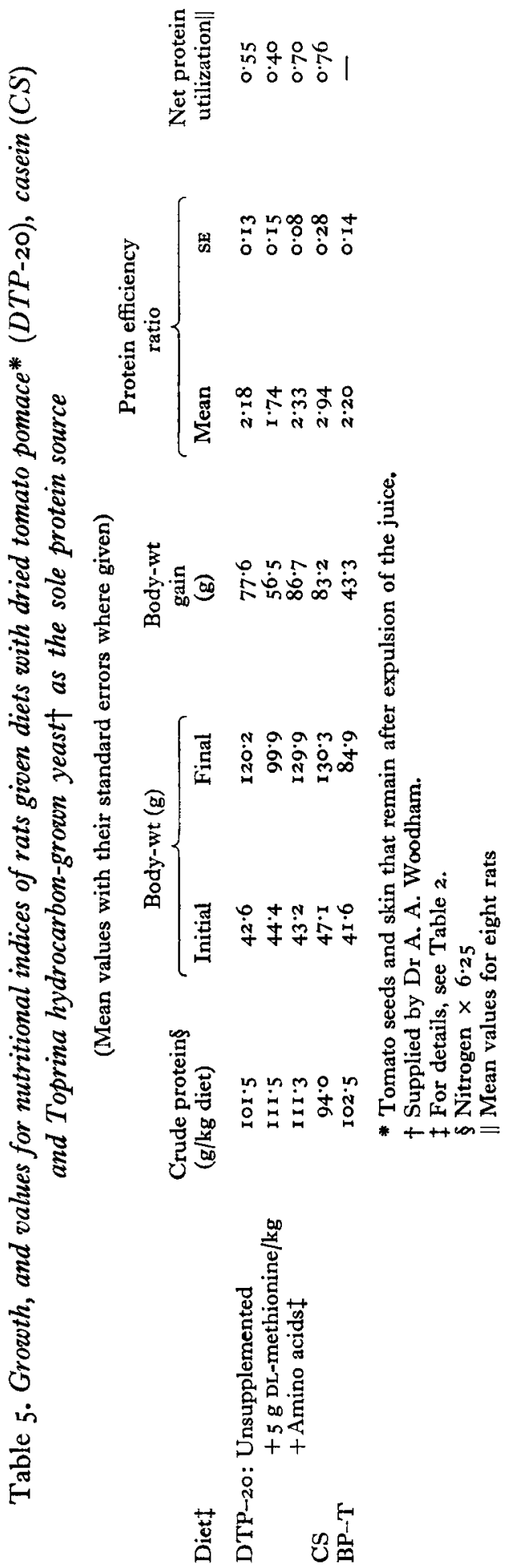


may be among the most toxic of amino acids. On the other hand, in the same work, levels of $50 \mathrm{~g}$ arginine $/ \mathrm{kg}$ diet were quoted as causing only a $16 \%$ reduction in growth.

In this context it should be mentioned that DTP-2o has a relatively high arginine content $(14 \cdot 2 \mathrm{~g} / \mathrm{kg}, 73 \mathrm{~g} / \mathrm{kg} \mathrm{CP})$, a value that is in the range of those reported for a number of plant protein sources, for example, soya-bean meal $(72 \mathrm{~g} / \mathrm{kg} \mathrm{CP})$, sunflower meal $(8 \circ \mathrm{g} / \mathrm{kg} \mathrm{CP})$, groundnut meal $(84 \mathrm{~g} / \mathrm{kg} \mathrm{CP})$ (Eggum, 1973). The arginine requirement in rat nutrition is not clearly settled (Greenstein \& Winitz, r96r), but the relatively high levels of arginine in some feedingstuffs of plant origin might be of particular interest and significance in metabolism, a subject that needs further study.

The total energy content of DTP-20 is $19 \cdot \mathrm{IMJ} / \mathrm{kg}$. Since there is virtually no lignification in the tomato fruit, it appears logical to expect that the crude fibre would consist mainly of the celluloses and hemicelluloses. The $\mathrm{N}$-free extract would incorporate starches and pentosan polysacharides, with a small proportion of total sugars $(5 \mathrm{I} \cdot \mathrm{g} / \mathrm{kg})($ Table $\mathrm{I})$.

The findings of this study were limited to the rat as an experimental animal. It is obvious, however, that other animal species should be tested. Although the dried pomace contains an average of only $200 \mathrm{~g} \mathrm{CP} / \mathrm{kg}$ and therefore is not considered a high-density protein supplement, it provides a relatively good-quality protein as judged by the nutritional indices determined in these experiments. In addition, its attractive appearance and slight bulkiness render this by-product a useful feeding-stuff ingredient.

The author thanks Mrs P. Atsele and Miss I. Siganou for laboratory and technical assistance, and $\operatorname{Dr} \mathrm{A}$. A. Woodham for amino acid analysis of a test sample of dried tomato pomace and, for making available the Toprina hydrocarbon-grown yeast.

\section{REFERENCES}

Association of Official Analytical Chemists (1970). Official Methods of Analysis, i ith ed. Washington, DC: Association of Official Analytical Chemists.

Bender, A. E. \& Miller, D. S. (1953). Biochem. F. 53, vii.

Christias, C., Couvaraki, C., Georgopoulos, S., Macris, B. \& Vomvoyanni, V. (1975). Appl. Microbiol.

29, 250.

Drouliscos, N. J. \& Bowland, J. P. (1969). Br. F. Nutr. 23, I I3.

Dubois, M. (1956). Analyt. Chem. 28, 350.

Eggum, B. O. (1973). Beretn. Forsøgslab. no. 406.

FAO/WHO (1965). Tech. Rep. Ser. Wld Hlth Org. no. 301.

Greenstein, J. P. \& Winitz, M. (I96I). Chemistry of the Amino Acids, vol. I. New York: John Wiley.

Kalaisakis, P., Papadopoulos, G., Boufidis, B., Zacharioudakis, S. \& Gourakou, A. (r97o). Poult. Sci. Rev. $\mathbf{x}, \mathbf{r}$.

Lewis, O. A. H. (1966). Nature, Lond. 209, 1239.

Maymone, B. \& Tiberio, M. (1959). Aliment. anim., Noyon 3, 119.

Miller, D. S. \& Bender, A. E. (1955). Br. F. Nutr. 9, 382.

Muramatsu, K., Odagiri, H., Morishita, S. \& Takeuchi, H. (I97I). F. Nutr. Ior, I I17.

National Research Council (1962). Publs natn. Res. Coun., Wash. no. 990.

Oser, B. L. (1951). F. Am. diet Ass. 27, 396.

Scott, M. L., Nesheim, M. C. \& Young, R. J. (I969). Nutrition of the Chicken. Ithaca, New York:

M. L. Scott \& Associates.

Smith, R. H. (1966). Adv. Chem. Ser. no. 57, p. 133.

Smith, R. H., Palmer, R. \& Reade, A. E. (r975). F. Sci. Fd Agric. 26, 785.

Stählin, A. (1957). Die Beurteilung der Futtermittel. Berlin: Neumann.

Woodham, A. A. \& Deans, P. S. (1973). Br. Poult. Sci. 14, 569. 